\title{
Priorities for Midwifery Research in Perth, Western Australia: A Delphi Study
}

Jennifer Fenwick, PhD, MNgSt, BHlthSc (Ng), RM

Associate Professor of Midwifery

Curtin University \& King Edward Memorial Hospital

School of Nursing and Midwifery

Curtin University of Technology

GPO Box U1987

Perth, W.A. Australia, 6845

e-mail: j.fenwick@curtin.edu.au

(Off print requests to JF)

Janice Butt, MA(Ed), PGCEA, ADM, RM RN (U.K.)

Senior Midwifery Teaching Fellow

School of Nursing and Midwifery

Curtin University of Technology \&

Coordinator Midwifery Education

King Edward Memorial Hospital

Perth, WA Australia

Associate Professor Jill Downie PhD, BappSc(Ng), RM , RN

Head of School

School of Nursing and Midwifery

Curtin University of Technology

GPO Box U1987

Perth, W.A. Australia, 6845

Leanne Monterosso

PhD, Bluey Day Senior Research Fellow,

School of Nursing and Public Health,

Churchlands Campus,

Pearson St Churchlands WA 6018.

Tel: 92736821 Fax: 9273 8699,

E-mail: l.monterosso@ecu.edu.au

Jennifer Wood MSc, PostGrad (mid), BSC (Nursing), DSc(Nursing)

Senior Lecturer \& Midwifery Educator

School of Nursing and Midwifery

Curtin University of Technology \&

WCHS King Edward Memorial Hospital

Perth WA.

\section{Acknowledgments:}

This work was funded by the Women's and Children's Health Service (King Edward Memorial Hospital). The authors would like to thank all the midwives who took the time to participate. 


\begin{abstract}
This paper reports a two-round Delphi study undertaken to identify the research priorities of midwives at five public maternity hospitals in Western Australian's metropolitan area of Perth. In round one, 117 midwives identified 64 different problems or issues for research. Using thematic content analysis these problems were grouped together and then collapsed to develop 17 specific research topics within four major categories. In round two, midwives $(n=152)$ were asked to rank how important each of the topic statements were to women, their families and midwives. Research focusing on 'the postnatal experience' was ranked by midwives as most important to the care of women and their families. From a midwives’ perspective the highest ranked topic was 'examining the professional issues that impact on midwives clinical practice (for example midwifery and medical collaboration, potential litigation and horizontal violence in the workplace). The results of the study demonstrate that Western Australian midwives, like their national and international colleagues, are concerned about the delivery and organisation of maternity services, the invisibility of the postnatal experience and how to operationalize evidence based care in the clinical area.
\end{abstract}

\title{
Key Words
}

Delphi study, Evidence-based practice, Midwifery, Postnatal care, Research priority, Service delivery 


\section{INTRODUCTION}

Over the years, researchers and clinicians have been distanced by seemingly impenetrable barriers. This may be partly explained because research performed solely in academic or clinical settings can lead to disparity between theory and practice $^{1,2}$. Collaborative research undertaken by nurse/midwifery academics and clinicians has been recommended as one strategy for generating clinically meaningful nursing/midwifery knowledge ${ }^{3}$. As other areas of nursing have demonstrated ${ }^{4-7}$, research priorities identified by midwives directly involved in the care of women, infants and their families are likely to have particular relevance to the profession.

The work presented in this paper was commissioned by Western Australia's (WA) only tertiary maternity referral hospital, and was viewed as the first step toward developing a collaborative research program to generate knowledge relevant to midwifery clinical practice in WA. The study was undertaken in response to the increasing importance of using research to inform practice in order to ensure evidence-based practice in the clinical setting. A fundamental step in this process is the conversion of information expressed as needs derived from practice, into focused, structured research questions that can be studied empirically ${ }^{8,9}$.

This study is set within the broader national midwifery context. Work conducted by the Australian Midwifery Action Project (AMAP) ${ }^{10}$, a comprehensive three-year study providing evidence on which to base strategic planning, workforce review, educational reform and policy direction, has drawn attention to the serious situation confronting Australian midwifery today ${ }^{11}$. One of the major issues identified by AMAP was the lack of empirical data not only in relation to midwifery workforce numbers and education, but also concerning how Australian midwives view themselves, their role and the future directions for the profession. It was, therefore, 
timely to conduct a survey of WA midwives to identify meaningful, clinically based midwifery research priorities.

\section{AIM}

The aim of this study was to identify the maternity health care research priorities of midwives practising in the metropolitan area of Perth. The objectives of the study were to:

- generate knowledge about questions or problems associated with current midwifery practice;

- identify midwifery priorities for future research as they relate to perceived gaps and needs; and

- assist each participating maternity institution to foster a research culture by identifying issues of specific relevance to their individual midwifery workforce.

\section{METHOD}

In this study, a replication of the two-round Delphi survey method used by Barrett et al ${ }^{1}$, Monterosso ${ }^{7}$ and Downie ${ }^{12}$ was undertaken. The Delphi Technique has been defined as a way of facilitating and structuring a group communication process based on the input of individuals ${ }^{13}$. The method developed by Helmer ${ }^{14}$ in 1967 involved interacting with group members individually to provide collective feedback of emerging consensus. Individuals are given an opportunity to reconsider their initial positions in light of group trends and make any adjustments they feel appropriate. The Delphi process does not involve face-to-face contact, therefore, participants remain anonymous and domination by particular individuals is avoided. The strength of this approach is that it achieves consensus without eliminating the 
minority view ${ }^{15,16}$. Use of such democratic processes generates group opinions that are truly representative.

The Delphi technique uses a series of consecutive questionnaires to aggregate the judgments of a group of individuals or experts. The first questionnaire can use open or closed questions, or as in this study, ask participants to create a list of ideas, problems and/or statements ${ }^{17}$. Responses are analysed, summarised and fed back to the group in the form of a second round questionnaire. The process is continued until sufficient information is obtained or consensus has been achieved ${ }^{18}$. Commonly, two or three rounds are used ${ }^{16,19}$ although modified versions of the technique have appeared in the literature over recent years ${ }^{20}$. The results of the final questionnaire are tabulated and presented as the final statement of group consensus.

\section{Participants}

Five hundred and ninety one midwives employed at five public hospitals in the Perth metropolitan area were invited to participate in the first round of the Delphi study. These five institutions have a cumulative annual birth rate of 8,000, which accounts for half of all the births recorded in the Perth Metropolitan area ${ }^{21}$. In Round Two 506 midwives were invited to participate. As suggested by French and associates

${ }^{22}$ this included midwives who did not previously participate in round one. The reduced number was attributed to the attrition and movement of midwives between the two data collection phases.

\section{Data Collection}

Prior to implementation of the study, information fliers supported by information sessions, were provided in each hospital to ensure recruitment of as many 
midwives as possible. A Round One questionnaire and demographic sheet, with an information letter and prepaid envelope, were attached to midwives’ payslips between October 2002 and April 2003. Midwives indicated their consent to participate by completing the questionnaire and returning it to the research assistant. Questionnaires were coded to enable identification of those that participated in both round one and two. The Round Two questionnaires, with an information letter and prepaid envelope, were distributed in the same manner during July and August 2003. No further rounds were considered appropriate as consensus was achieved with the Round Two data.

\section{Ethical Approval}

Permission was sought to conduct the study from the Directors of Nursing and Midwifery at each maternity hospital. Ethical approval was then sought and granted from Edith Cowan University (ECU) and the ethics committee's of each of the five maternity hospitals.

\section{FINDINGS: ROUND ONE}

Of the 551midwives who were invited to participate in Round One, 155 midwives (26\%) returned the demographic data sheet only and 117 midwives (20\%) returned completed Round One questionnaires. The response rate across all the participating hospitals ranged from $17 \%$ to $28 \%$.

The average participant was aged between 40 and 49 years, had over 15 years of midwifery experience and worked clinically with women and their families across the childbirth continuum. Half of the participants were either level one or two registered midwives and nearly 52\% stated they worked part time. Tables 1-7 present 
the demographic characteristics of Round One participants as well as those midwives who also completed the Round Two questionnaire.

The Round One questionnaire was adapted from a study undertaken with nurses working in paediatric oncology by the Western Cancer Consortium ${ }^{3}$. Midwives were asked to provide a list of five important questions, problems or approaches relating to the midwifery care of women and their families during pregnancy, childbirth and early parenting that they believe should be studied.

A total of 556 statements were collected with midwives identifying 64 different questions, problems or approaches that they believed important to research. Using thematic content analysis, the researchers independently identified five major categories, each with a number of subthemes. As suggested by French and associates

${ }^{22}$, categorizing the data independently and reaching a consensus in this manner is one way to deal with large amounts of data generated by a qualitative first round. The five categories were labelled; 'professional issues', 'antenatal issues', 'labour and birth issues', 'postnatal issues' and 'miscellaneous'. Discussion and agreement between the authors was then used to collapse the subthemes to develop 17 specific research topics within four major categories for the Round Two questionnaire (Appendix 1). The large number of qualitative responses collected in Round One will be detailed elsewhere.

\section{FINDINGS: ROUND TWO}

In Round Two, 17 research topics were listed under four specific headings and respondents were asked to respond to three research questions with regard to each topic. These were,

1. How important is this research topic to the care of women? 
2. How important is this research topic to the care of women's families? and

3. How important is this research topic to midwifery?

The midwives were asked to respond to each question using a seven point Likert-type scale with 1 indicating low priority and 7 indicating high priority.

A total of 152 midwives, a response rate of 30\%, completed this round. Fifty nine percent $(n=90)$ of the participants had also completed round one. The demographic characteristics of those midwives only participating in Round Two were not collected. The only noticeable difference between the participants in Round One and those midwives who completed both rounds related to tertiary qualifications. There were a higher percentage of respondents completing both rounds who identified themselves as having tertiary level education (11.1\% as compared to $6.5 \%)$. The results generated from the round two analyses were similar regardless of place of employment and age.

Data was managed using the Statistical Package for Social Sciences (SPSS v.10). Frequency and descriptive statistics were calculated. Ratings for research topics were computed according to means. Cronbach’s standardised alpha coefficient was used to estimate the internal consistency reliability of each of the subscales. This analysis was undertaken to confirm that each group of research questions or topic correlated to some extent and referred to the same overall category. Nunnally and Bernstein ${ }^{23}$ suggest that reliability estimates should be at least 0.80 .

\section{Internal consistency of categories}

The Cronbach’s alpha coefficient ranged from 0.5387 to 0.9047 for the questionnaire sub-scales. The sub-scale titled 'antenatal issues' scored a low level of 
internal consistency using this measure. This suggests that the statements in the category need further refinement. Overall, however, the results indicated a moderate to high degree of internal consistency. The results are shown in Table 8.

\section{Ranking of research categories}

The importance of the four research categories was compared using mean scores. 'Postnatal Issues' scored the highest followed by 'Antenatal Issues' and 'Labour and Birth Issues'. The category of 'Professional Issues' was ranked fourth (see Table 9).

\section{Overall importance of research categories}

Mean scores (with a possible range of 3 to 21) were used to rank the 17 research topics from most important to least important research priority. Table 10 presents the results in descending order of priority. The top two ranked priorities were both related to the postpartum period. These two topics, albeit in reverse order, were also ranked first and second for the care of women and their families. However, as a priority for midwives, these two postpartum issues ranked $10^{\text {th }}$ and $12^{\text {th }}$ respectively.

\section{Research topics important to the care of women.}

A summary of the ranked priorities from most important to least important for the care of the childbearing woman is shown in Table 11. All three postnatal topics scored in the top five. The most highly ranked topic was 'women's perceptions of their experience and postpartum recovery over both short and long term'. The second related to the need to 'assess the evidence-based knowledge of both women and midwives in relation to postnatal issues such as early discharge and postnatal 
depression (PND)'. 'Investigating women’s experiences and expectations of childbirth', categorised as a professional issue but related to the postnatal period, was ranked third.

\section{Research topics important to the care of women's families}

The three postnatal topics were ranked as most important to the care of women’s families. Once again the professional issue, ‘women’s childbirth experiences and expectations’ scored highly. A summary of this data is presented in Table 12.

\section{Research topics important to midwifery}

The research topics ranked from most to least important for midwives are shown in Table 13. As the results demonstrated, the midwives in this study considered their research priorities to be quite different to those identified for the care of women and their families. The highest ranking topic was 'examining the professional issues that impact upon midwives clinical practice (e.g. midwifery and medical collaboration, potential litigation and horizontal violence in the workplace).' In relation to the previous question of 'importance to women's families' this topic had been ranked as one of the least important (twice ranked at $16^{\text {th }}$ and once at $15^{\text {th }}$ ).

Two other professional issues: ‘Exploring women’s perceptions of midwifery led care’ and 'investigating current childbirth experiences and expectations’ ranked third and fourth respectively. Five of the top ten topics identified as most important to midwives belonged to the category of 'intrapartum issues'. As reported earlier the highly ranked postpartum issue of 'assessing the evidence-based knowledge of women and midwives in the early postnatal phase' ranked $10^{\text {th }}$. 


\section{Differences between midwives priorities depending on work place}

The research priorities of midwives working at the tertiary maternity referral hospital were also examined and compared to those midwives working at smaller public hospitals. There were minor differences in the overall ordering of the topics with postnatal issues remaining the most important. The most noticeable differences related to the intrapartum topics: 'Evaluate the discrepancy between evidence based practice guidelines and their implication for practice in relation to: pre-labour SROM at term' was ranked seventh rather than $10^{\text {th }}$ and care of the bladder in labour became more important moving from $12^{\text {th }}$ to $10^{\text {th }}$ place. The qualitative analysis undertaken in round one suggested this was probably related to midwives concerns regarding the high rates of induction and epidural use in the tertiary maternity referral sector.

\section{Research topics ranked as least important.}

The three research topics ranked as least important were also examined and compared. The results are presented in Table 14. 'Development of a preceptorship model that promotes communication between clinicians and academic staff' was consistently ranked as least important regardless of the research question being posed.

\section{DISCUSSION}

The results of this two-round Delphi study, while not necessarily reflecting the views of the majority of Australian midwives, does provide valuable insight into the research priorities of a cohort of WA midwives and the important questions facing both the profession and women today. The response rate was considered acceptable for a Delphi study ${ }^{19,24}$. A limitation of the research was that demographic 
information was not collected from midwives who only responded to the Round Two questionnaire. The participant characteristics gathered from participants who responded to both rounds were, however, representative of both the WA and general Australian midwifery population ${ }^{25,26}$ which is an important feature of the Delphi method $^{22}$.

The midwives in this study were particularly concerned about the impact of care and advice during the early postnatal period, support offered prior to transfer home, how to identify and assist women with postnatal depression, and breastfeeding. Research into issues affecting the postnatal period such as women's expectations and experiences of childbirth, perineal trauma and optimising bladder function were also rated highly. There is strong agreement in the data that, from the woman's and family's perspective, the postpartum period should be the focus of extensive midwifery-led research. These findings are particularly significant given the impact, but relative invisibility, of health problems that many woman face after childbirth as evidenced by MacArthur et al ${ }^{27}$, Glazener et al $^{28}$ and Brown and Lumley ${ }^{29}$.

More recent work focusing on the level of midwifery postnatal support also suggests that the midwives concerns are not ill founded. Cooke and Stacey ${ }^{30}$ surveyed 365 New South Wales women and found that over $40 \%$ of the participants felt they did not have their health needs met during the postpartum period. These findings unfortunately continue to confirm earlier work by Emery et al ${ }^{31}$ and Holmes et $\mathrm{al}^{32}$, with the authors concluding that midwifery support after childbirth needs to be improved for both multiparous and primiparous women. Postpartum care is perhaps the one area of clinical practice that midwives could claim to make the greatest impact given the lack of obstetric interest in this aspect of the childbirth process ${ }^{33}$. 
When participants were asked to rank the research topics in terms of importance to midwives there was an obvious change of focus. Not surprisingly professional issues that impact on clinical practice rated highly. Midwives were concerned about the paradox between midwifery and medicine, the 'fear' of litigation and it's impact on practice, as well as issues such as stress and horizontal violence in the work place, staffing levels and retention of midwives.

These findings support the work of other Australian researchers. For example, researching professional aspects of midwifery practice was identified as a priority by midwives in South Australia ${ }^{34}$. Although the response rate in this study was extremely poor $(8.3 \% n=31 / 370)$ the four other identified research areas (water birth, midwifery models of care, breastfeeding and perineal repair) reflect a synergy with the WA data. Professional issues related to midwifery identity, status and autonomy as well as issues such as medical dominance and a concern over rising childbirth intervention rates were also identified in a 1995 random population based sample of 240 Victorian midwives ${ }^{35}$. Although this data was collected nearly ten years ago some of the issues considered most important to the profession remain the same.

Similar results have recently been published by Brodie ${ }^{36}$, whose study undertaken as part of the AMAP project, sought to identify the barriers to midwifery practice in Australia. From the 563 responses collected seven key themes were identified. Professional and societal recognition, organisation of services, supply of midwives, stress and workload, and restricted opportunities to practice are all issues that correspond to concepts raised by the midwives in this study and are intrinsically interlinked to each other. As Brodie ${ }^{36}$ stated these findings also resonate internationally. One example is the work of Ball and associates ${ }^{37}$ who found that similar issues contributed significantly to the attrition of the midwifery workforce in 
the United Kingdom (UK). Other well known UK researchers ${ }^{38-40}$ have reported comparable findings with staff shortages, stress, rising childbirth intervention rates and conflicting ideologies all being identified as issues for the profession. Indeed the importance of researching these problems has been acknowledged and recognised by the International Confederation of Midwives (ICM) who identified these as priority areas for future international midwifery research in 2002 at the ICM Congress ${ }^{41}$.

One of the striking findings of the study was the confusion midwives expressed over implementing evidence-based practice (EBP) in the clinical area, particularly in the intrapartum period. The qualitative analysis of the Round One data elicited a 'sense of frustration' with some medical colleagues over a failure to operationalize polices and procedures based on best evidence. Specific practices included: the use of electronic fetal monitoring (EFM); management options and choices for women with pre-labour spontaneous rupture of membranes (PROM); the continued focus on 'length' of second stage as a prelude to intervention rather than maternal and fetal wellbeing and the previous progression of the labour; and how best to optimise bladder and pelvic floor function during labour and birth. As Kennedy and Lowe ${ }^{42}$ suggested, this may reflect the dilemma between science and midwifery concerning common clinical problems such as those identified in this study. It appears to be indicative of the, "paradigms and paradoxes of how we use knowledge and intervention in the health care of women” 42 p. 91 .

As suggested by Stewart ${ }^{43}$ the midwifery profession has used EBP as a tool in the argument against rising rates of obstetric childbirth intervention. In many instances, however, it has not lived up to this expectation. Part of the problem is that the step from best evidence to best practice is often not a simple one ${ }^{44}$ with EBP being a value-laden concept ${ }^{45,43}$. Even when there is irrefutable scientific evidence it 
is the clinician that enacts the practice. The individual practitioner's responses are based not only on their own philosophy but also those of the dominant culture ${ }^{46}$. For many western world countries this means a maternity care system that is entrenched in pathology and driven by intervention management ${ }^{42,47,48}$. Stewart ${ }^{43}$ argued that authoritarian knowledge, such as this, retains and supports social order and in so doing overrides evidence. It becomes incredibly difficult to implement and enact evidence-based care practices when they go against the cultural norms of the institution ${ }^{49}$. As the results in this study demonstrate, and as Stewart ${ }^{43}$ advocates, there is a real and immediate need to research the difficulty of implementing EBP when it conflicts with the prevailing culture.

A disappointing finding of the study was the consistency with which midwives rated 'preceptorship' as a low priority. This may reflect the evidence that suggests that preceptors often receive limited recognition for undertaking their role ${ }^{50,51}$, despite acknowledgment that they provide an essential link between theoretical learning and clinical practice ${ }^{52-55}$. The limited emphasis on the effect of preceptorship on the preceptor may be the reason for this issue rating as a low priority area.

\section{CONCLUSION}

This study has generated 17 priority areas for midwifery research in Western Australian. The results of the study represent the views and opinions of a cohort of WA midwives who are currently practising 'at the coalface’. One of the important findings of the study, however, is the similarity between what midwives are saying both nationally and internationally. Similar to the results of the scoping exercise undertaken in the UK by Ross and associates ${ }^{49}$, the work of Brodie ${ }^{36}$ and the AMAP team ${ }^{10}$, all the priority areas identified by the WA midwives related to either the delivery of maternity services and/or the organisation of services, which are both 
interlinked and dependent on one another. Therefore, regardless of the context these findings have the potential for wider application and provide a basis on which to generate research that will be considered clinically relevant and important to both midwives and childbearing women and their families.

Secondly, this study highlights that midwives are concerned about their role and the impact they potentially have on health care outcomes for women and families in the postpartum period. There seems little doubt this is an area of genuine need. Congruent with the international literature the results of this study confirm that the postpartum component of maternity care needs to receive greater attention and resource allocation. The lack of base line data available in WA on women's expectations and/or satisfaction with the level of support received in the postpartum period, underscores the need for a large prevalence study. Midwifery-led research can then focus on updating patterns of postnatal care to better meet women's individual needs and preferences.

Finally, the study draws attention to the confusion some midwives experience in the clinical area when they are unable to practice according to the best evidence available. The reality of working within a medically dominated system potentially creates an immediate tension between the principles of midwifery management that are based on a holistic framework that considers pregnancy, birth and early parenting to be a normal but significant life event and the opposing medical view that considers birth to be potentially dangerous and only normal in hindsight ${ }^{56}$. For many midwives this situation reinforces their powerlessness to effectively implement research findings and change practice. Wide spread system change, supported by relevant and high quality research, is needed if midwives are to successfully provide excellence in midwifery care and form one of the key elements in sound public health planning ${ }^{57}$. 


\section{ACKNOWLEDGMENTS}

This work was funded by the Women's and Children's Health Service, King Edward

Memorial Hospital for Women, Perth. Western Australia. The authors would like to thank all the midwives who took the time to participate in the study. 


\section{REFERENCES}

1. Barrett S, Kristjanson L, Sinclair T, Hyde S. Priorities for adult cancer nursing research: A Western Australian Replication. Cancer Nursing 2001; Apr 24(2):88-98 2. Mulhall A. Nursing, research, and the evidence. Evidence-Based Nursing 1998; 1(1): 4-6.

3. Western Consortium for Cancer Nursing Research, W.C.F.C.N.R. Cancer Nursing 1987; 10: 319-326

4. Chang E, Daly J. Clinical research priorities in oncology nursing: an Australian perspective. International Journal of Nursing Practice 1996; 2(1):21-28

5. Bell P, Daly J, Chang E. A study of the educational and research priorities of registered nurses in rural Australia. Journal of Advanced Nursing 1997; 25(4): 794800

6. White K, Wilkes L. The specialist breast cancer nurse: an evolving role. Collegian 1999; 6(4): 8-14

7. Monterosso L. Priorities of paediatric cancer nursing research in Western Australia: A Delphi Study. Contemporary Nurse 2001; 11: 142-152

8. Closs S J, Cheater FM. Evidence for nursing practice: A clarification of the issues. Journal of Advanced Nursing 1999; 30(1): 10-17.

9. Flemming K. Asking answerable questions. Evidence-based Nursing 1998; 1(2): 36-37.

10. AMAP. Australian Midwifery Action Project. Final Report. Centre for Family health and Midwifery. University of Technology, Sydney, 2003.

11. Tracy S, Barclay L, Brodie P. Issues in Contemporary Workforce and Education of Australian Women. Australian Health Review 2000; 3(4): 100-110 
12.Downie J. Nursing research priorities in community and women's health.

Fremantle WA: Fremantle Hospital and Health Service, 1998; 1-20.

13. Linstone HA, Turoff M. Using Delphi Method: Techniques and Applications.

Reading: Addison-Wesley MA, 1975.

15. Helmer O. Analysis of the future: The Delphi technique. Santa Monica, CA Rand Corp 1967.

15. Loughlin KG, Moore LF. Using Delphi to achieve congruent objectives and activities in a paediatric department. Journal of Medical Education 1979; 54(2): 101106

16. Roberts K, Taylor B. Nursing research process. An Australian perspective.

Victoria; Nelson Thomson Learning $2^{\text {nd }}$ ed 2002

17. Cluett ER, Bluff R. Principles and practice of research in midwifery. Sydney;

Bailliere Tindall 2000.

18. Kennedy HP. A model of exemplary midwifery practice: results of a Delphi study. Journal of Midwifery \& Women's Health, 2000; Jan/Feb 45(1): 4-19

19. McKenna H (1994) The Delphi technique: a worthwhile research approach for nursing? Journal of Advanced Nursing 19, 1221-1225

20. Crisp J, Pelletier D, Duffield C, Nagy S, Adams A . 'It's all in a name: when is a delphi study not a delphi a study?' Australian Journal of Advanced Nursing 1999: 16(3):32-37

21.Gee V, O'Neill MT. Perinatal Statistics in Western Australia, 1998. Sixteenth Annual Report of the Western Australian Midwives' Notification System. Health Department of Western, Australia 2000.

22. French P, Ho YY, Lee L-S. A Delphi survey of evidenced-based nursing priorities in Hong Kong. Journal of Nursing Management 2002; 10: 265-273 
23. Nunnally JA, Berstein I. Psychometric theory. New York: McGraw-Hill, 1994.

24. McKenna H, Hasason F, Smith M. A Delphi survey of midwives and midwifery student to identify non-midwifery duties. Midwifery 2002; 18: 314-322

25. Cantrill RM, Creedy DK, Cooke M. How midwives learn about breastfeeding. Australian Journal of Midwifery 2003; 16(3): 25 - 30

26. Australian Institute of Health and Welfare (AIWH), Nursing labour force 1999. AIHW (National Health Labour Forces Series), Canberra, ACT, 1999.

27. MacArthur C, Lewis M, Knox EG. Health after childbirth. London, HMSO, 1991. 28. Glazener CMA, Abdella M, Stroud P, Naji S, Templeton A, Russell IT. Postnatal maternal morbidity: extent, causes, prevention, and treatment. Br J Obstet Gynaecol 1995; $102: 282-287$

29. Brown S, Lumley J. Maternal health after childbirth: results of an Australian population based survey. Br J Obstet Gynaecol 1998; 105 : 156-161

30. Cooke M, Stacey T. Differences in the evaluation of postnatal midwifery support by multiparous and primiparous women in the first two weeks after birth. Australian Journal of Midwifery 2003; 16(3): $18-24$

31. Emery JL, Scholey S, Taylor EM. Decline in breast feeding. Archives Disease Child 2000; 65: 369 - 372

32. Holmes W, Phillips J, Thorpe L. Initiation rate and duration of breast-feeding in the Melbourne Aboriginal community. Australian and New Zealand Journal of Public Health 1997; 21(5): $504-510$

33. Alber LL. Health problems after childbirth. Journal of Midwifery \& Women’s Health 2000; Jan/Feb 45(1): 55-57

34. Pincombe J. SA Members research results. Australian Midwifery News 2003; 3(1): 
35. Watson L, Potter A, Donohue L. Midwives in Victoria, Australia: a survey of current issues and job satisfaction. Midwifery 1999 15: 216-231

36. Brodie P. Addressing the barriers to midwifery - Australian midwifery speaking out. Australian Journal of Midwifery 2002; 15(3) 5-14

37. Ball L, Curtin P, Kirkham M. Why do midwives leave? Sheffield: Women’s informed childbearing and health research group, University of Sheffield, 2002.

38. Cavanagh S, Snape J. Stress in student midwives: an occupational perspective. British Journey of Midwifery 1997; 5: 528-533

39. Cavanagh S, Snape J. Educational sources of stress in midwifery students. Nurse Education Today 1997; 17:128-134

40. Kirkham M, Stapleton H (1999) The culture of midwifery in the NHS in England. Journal of Advanced Nursing. 30: 732 - 739

41. Renfrew MJ, Raisler J, Kennedy H, Mudokwenyu-Rawdon C. Conducting international research in midwifery: a workshop held in the ICM Congress, Vienna, April 2002, Midwifery 2003; 19: 170-173

42. Kennedy HP, Lowe NK. Science and midwifery: Paradigms and paradoxes, Journal of Midwifery \& Women's Health 2001; March-April 46(2): 91-97

43. Stewart M. Whose evidence counts? An exploration of health professionals' perceptions of evidenced-based practice, focusing on the maternity services. Midwifery 2001; 17: 279-288

44. Grol R, Grimshaw J. From best evidence to best practice: effective implementation of changes in patient's care. The Lancet 2003; 362: 1225 - 1230 45. Grol R. Beliefs and evidence in changing clinical practice. BMJ 1997; 315: 418 421 
46. Sanson-Fisher RW. Diffusion of innovation theory for clinical change. MJA 2004; March 15, 180(6): S55-S56

47. Johanson R, Newburn M, Macfarlaine A. Has the medicalisation of childbirth gone to far? BMJ 2002; 324: 892-895

48. Leap N, Barclay L, Sheehan A. Results of the Australian Midwifery Action Project Education Survey. Paper 2: Barriers to effective midwifery education as identified by midwifery course coordinators. Australian Journal of Midwifery 2003; 16(3): $6-11$

49. Ross F, Smith E, Mackenzie A, Masterson A (2004) Identifying research priorities in nursing and midwifery service delivery and organisation: a scoping study. International Journal of Nursing Study 2004; 41: 547-588

50. Grealish L, Carroll G. Beyond preceptorship and supervision: a third clinical teaching model emerges for Australian nursing education. Australian Journal of Advanced Nursing 1997; 15(2): 3-11

51. Laforet-Fliesser A, Ward-Griffin DP, Beynon S. Self-efficacy of preceptors in the community: A partnership between service and education. Nursing Education Today 1999; 19: 41-52

52. Chickeralla B, Lutz W. Professional nurturance: preceptorship for undergraduate nursing. American Journal of Nursing 1981; 81(1): 107 - 109

53. Dobbs KK. The senior preceptorship as a method of anticipatory socialization of baccalaureate nursing students. Journal of Nursing Education 1998; 27(4): 167-170 54. Dibbert C, Goldenberg D. Preceptors' perception of benefits, rewards and commitment of the preceptor role. Journal of Advanced Nursing 1995; 21: 1144-1151 55. Myrick F. Preceptorship and critical thinking in nursing education. Journal of Nursing Education 2002; 41(4): 154-165 
56. Symon, A. Interprofessional and peer criticism: a side effect of litigation? Journal of Obstetrics and Gynaecology, 1999; 19(3):248 - 252.

57. Kaufmann T. Midwifery and public health. MIDIRS Midwifery Digest March 2002; S23-S26 
Tables 1 - 7: Demographic characteristics of the Round One and Two participants

Table 1: Age of participants

\begin{tabular}{|l|c|c|c|c|}
\hline & \multicolumn{2}{|c|}{ Round One Only } & \multicolumn{2}{c|}{ Both Rounds } \\
\hline & Number & Percentage & 4 & 4.4 \\
\hline $20-29$ & 4 & 2.6 & 23 & 25.6 \\
\hline $30-39$ & 39 & 25.5 & 46 & 51.1 \\
\hline $40-49$ & 72 & 47.1 & 15 & 16.7 \\
\hline $50-59$ & 36 & 23.5 & 2 & 2.2 \\
\hline $60-69$ & 2 & 1.3 & $\mathbf{9 0}$ & $\mathbf{1 0 0}$ \\
\hline Total & $\mathbf{1 5 3}$ & $\mathbf{1 0 0}$ & & \\
\hline Missing & 2 & & & \\
\hline
\end{tabular}

Table 2: Summary of midwifery experience

\begin{tabular}{|l|c|c|c|c|}
\hline & \multicolumn{2}{|c|}{ Round One Only } & \multicolumn{2}{c|}{ Both Rounds } \\
\hline & Number & Percentage & Number & Percentage \\
\hline Under 5 years & 17 & 11.2 & 12 & 13.3 \\
\hline $5-10$ years & 35 & 23.0 & 20 & 22.2 \\
\hline $11-15$ years & 21 & 13.8 & 13 & 14.4 \\
\hline $16-20$ years & 31 & 20.4 & 19 & 21.1 \\
\hline Over 20 years & 48 & 31.6 & 26 & 28.9 \\
\hline Total & $\mathbf{1 5 2}$ & $\mathbf{1 0 0}$ & $\mathbf{9 0}$ & $\mathbf{1 0 0}$ \\
\hline Missing & 3 & & 0 & Maximum no: years of experience 33 \\
\hline
\end{tabular}

Table 3: Years of midwifery experience in present institution

\begin{tabular}{|l|c|c|c|c|}
\hline & \multicolumn{2}{|c|}{ Round One Only } & \multicolumn{2}{c|}{ Both Rounds } \\
\hline & Number & Percentage & Number & Percentage \\
\hline Less than 5 years & 50 & 32.7 & 34 & 37.8 \\
\hline $5-10$ years & 46 & 30.1 & 27 & 30.0 \\
\hline $11-15$ years & 27 & 17.6 & 16 & 17.8 \\
\hline $16-20$ years & 19 & 12.4 & 8 & 8.9 \\
\hline Over 20 years & 11 & 7.2 & 5 & $\mathbf{1 0 0}$ \\
\hline Total & $\mathbf{1 5 3}$ & $\mathbf{1 0 0}$ & $\mathbf{9 0}$ & 0 \\
\hline Missing & 2 & & \multicolumn{2}{c|}{ Maximum no: years at hospital = 29 } \\
\hline
\end{tabular}

Table 4: Areas in which participants were currently working

\begin{tabular}{|l|c|c|c|c|}
\hline & \multicolumn{2}{|c|}{ Round One Only } & \multicolumn{2}{c|}{ Both Rounds } \\
\hline & Number & Percentage & Number & Percentage \\
\hline Midwifery & 113 & 74.3 & 65 & 73.0 \\
\hline Community & 5 & 3.3 & 4 & 4.5 \\
\hline Neonatal nursery & 11 & 10.5 & 8 & 9.0 \\
\hline Other & 18 & 11.8 & 12 & 13.5 \\
\hline Total & $\mathbf{1 5 2}$ & $\mathbf{1 0 0}$ & $\mathbf{8 9}$ & $\mathbf{1 0 0}$ \\
\hline Missing & 3 & & 1 & \\
\hline
\end{tabular}


Table 5: Job classification

\begin{tabular}{|l|c|c|c|c|}
\hline & \multicolumn{2}{|c|}{ Round One Only } & \multicolumn{2}{c|}{ Both Rounds } \\
\hline & Number & Percentage & Number & Percentage \\
\hline $\begin{array}{l}\text { Clinical Consultant / } \\
\text { Manager }\end{array}$ & 15 & 9.9 & 10 & 11.2 \\
\hline RM level 2 & 57 & 37.5 & 33 & 37.1 \\
\hline RM level 1 & 66 & 43.4 & 33 & 37.1 \\
\hline Other & 14 & 9.2 & 13 & 14.6 \\
\hline TOTAL & $\mathbf{1 5 2}$ & $\mathbf{1 0 0}$ & $\mathbf{8 9}$ & $\mathbf{1 0 0}$ \\
\hline Missing & 3 & & 1 & \\
\hline
\end{tabular}

Table 6: Employment terms

\begin{tabular}{|l|c|c|c|c|}
\hline & \multicolumn{2}{|c|}{ Round One Only } & \multicolumn{2}{c|}{ Both Rounds } \\
\hline & Number & Percentage & 42 & 47.2 \\
\hline Full time & 61 & 40.1 & 41 & 46.0 \\
\hline Part time & 79 & 51.9 & 6 & 6.7 \\
\hline Casual & 12 & 8.0 & $\mathbf{8 9}$ & $\mathbf{1 0 0}$ \\
\hline Total & $\mathbf{1 5 2}$ & $\mathbf{1 0 0}$ & 1 & \\
\hline Missing & 3 & & & \\
\hline
\end{tabular}

Table 7: Midwifery qualification

\begin{tabular}{|l|c|c|c|c|}
\hline & \multicolumn{2}{|c|}{ Round One Only } & \multicolumn{2}{c|}{ Both Rounds } \\
\hline $\begin{array}{l}\text { Midwifery Hospital registration } \\
\text { certificate only }\end{array}$ & Number & Percentage & Number & Percentage \\
\hline $\begin{array}{l}\text { Midwifery Hospital registration } \\
\text { certificate plus another } \\
\text { qualification }\end{array}$ & 114 & 73.5 & 61 & $* 11.1$ \\
\hline $\begin{array}{l}\text { Gained midwifery registration } \\
\text { through other means than } \\
\text { hospital certificate }\end{array}$ & 26 & 16.8 & 16 & 17.8 \\
\hline Student Midwife & 1 & 0.5 & 16 & 1.1 \\
\hline TOTAL & $\mathbf{1 5 1}$ & $\mathbf{1 0 0}$ & $\mathbf{8 8}$ & $\mathbf{1 0 0}$ \\
\hline Missing & 4 & & 2 & \\
\hline
\end{tabular}

\section{Table 8:}

Internal Consistency reliability of research categories in the Round Two questionnaire according to Cronbach’s standardised alpha Coefficient

\begin{tabular}{|l|l|l|l|}
\hline Subscale & $\begin{array}{l}\text { Importance to } \\
\text { Midwifery }\end{array}$ & Importance to Woman & Importance to family \\
\hline Professional Issues & 0.7085 & 0.7655 & 0.8305 \\
\hline Antenatal Issues & 0.5387 & 0.6434 & 0.7357 \\
\hline Intrapartum Issues & 0.8577 & 0.8214 & 0.9047 \\
\hline Postpartum Isses & 0.7582 & 0.7855 & 0.7381 \\
\hline
\end{tabular}

Table 9:

Research categories ranked as most important according to standardised means

\begin{tabular}{|l|l|l|l|}
\hline Subscale & Mean & STD & Total Mean \\
\hline Postpartum Issues & 6.3225 & 6.7180 & 56.9021 \\
\hline Antenatal Issues & 6.1333 & 4.9953 & 36.800 \\
\hline Labour Issues & 5.9261 & 15.8950 & 124.4483 \\
\hline Professional Issues & 5.8793 & 12.0861 & 88.1892 \\
\hline
\end{tabular}


Table 10:

Research topics ranked from most important to least important

\begin{tabular}{|c|c|c|c|}
\hline Topic & Mean & SD & $\mathbf{N}$ \\
\hline $\begin{array}{l}\text { 1. Assess the evidence-based knowledge of both women and midwives } \\
\text { during the early postnatal phase (for example, early discharge, PND } \\
\text { and the impact of labour and birth outcomes on the early parenting } \\
\text { period) (16). }\end{array}$ & 19.1329 & 2.5653 & 143 \\
\hline $\begin{array}{l}\text { 2. Explore women's immediate and longer-term (6 months) perception } \\
\text { of their postpartum experience and physical recovery (15). } \\
\text { Subsidiary questions: } \\
\text { - Explore women's perceptions of the care and advice received from } \\
\text { - } \quad \text { Expldwives in preparation for early parenting. }\end{array}$ & 19.0694 & 2.5955 & 144 \\
\hline $\begin{array}{l}\text { 3.Investigate women's current expectations and experiences of } \\
\text { childbirth (3). }\end{array}$ & 18.8278 & 2.6122 & 151 \\
\hline $\begin{array}{l}\text { 4. Explore current issues related to breastfeeding from the perspective } \\
\text { of midwives, women and other health care professionals (17). }\end{array}$ & 18.6458 & 3.0278 & 144 \\
\hline 5. Identify strategies to increase antenatal midwifery led services (7) & 18.6026 & 2.8591 & 151 \\
\hline 6. Explore women’s perceptions of midwifery led care (2). & 18.2185 & 3.0461 & 151 \\
\hline $\begin{array}{l}\text { 7. Undertake a needs analysis of women during the antenatal phase of } \\
\text { pregnancy (6) } \\
\text { Subsidiary question: } \\
\text { - What factors influence the uptake and outcome of antenatal } \\
\text { education for women. }\end{array}$ & 18.2000 & 2.8118 & 150 \\
\hline $\begin{array}{l}\text { 8. Investigate suturing versus none suturing of perineal lacerations } \\
\text { (14). }\end{array}$ & 17.9797 & 2.8439 & 148 \\
\hline $\begin{array}{l}\text { 9. Explore midwives' current expectations and experiences of } \\
\text { promoting active birth strategies with women in labour (8). }\end{array}$ & 17.9007 & 2.8560 & 151 \\
\hline $\begin{array}{l}\text { 10. Evaluate the discrepancy between evidence based practice } \\
\text { guidelines and their implication in practice in relation to: pre-labour } \\
\text { SROM at term (10). }\end{array}$ & 17.8792 & 2.9681 & 149 \\
\hline $\begin{array}{l}\text { 11. Explore the role of the midwife from the perspective of midwives, } \\
\text { women and other health care professionals (1). }\end{array}$ & 17.8684 & 3.4597 & 152 \\
\hline $\begin{array}{l}\text { 12. Determine midwifery best practice to optimise bladder function } \\
\text { during labour and birth (13). }\end{array}$ & 17.7181 & 3.3753 & 149 \\
\hline $\begin{array}{l}\text { 13. Evaluate the discrepancy between evidence based practice } \\
\text { guidelines and their implication in practice in relation to: Routine } \\
\text { ARM and } 2^{\text {nd }} \text { stage management (11). }\end{array}$ & 17.7067 & 3.2472 & 150 \\
\hline 14. Evaluate the discrepancy between evidence based practice & 17.5839 & 3.0182 & 149 \\
\hline
\end{tabular}




\begin{tabular}{|l|l|l|l|}
\hline $\begin{array}{l}\text { guidelines and their implication in practice in relation to: Electronic } \\
\text { Fetal Monitoring(9). }\end{array}$ & & & \\
\hline $\begin{array}{l}\text { 15. Explore the impact of the increasing use of epidural analgesia on } \\
\text { midwives' clinical practice (12). }\end{array}$ & 17.5369 & 2.9899 & 149 \\
\hline $\begin{array}{l}\text { 16. Examine the professional issues that impact upon midwives' } \\
\text { clinical practice (for example, midwifery and medical collaboration, } \\
\text { potential litigation and horizontal violence in the workplace) (4). }\end{array}$ & 17.3092 & 3.3221 & 152 \\
\hline $\begin{array}{l}\text { 17. Develop a preceptorship model that promotes communication } \\
\text { between preceptors (clinicians) and academic staff, and that also meets } \\
\text { the needs and requirements of both the university and clinical facility } \\
\text { (5). }\end{array}$ & 15.7219 & 4.1298 & 151 \\
\hline & & & \\
\hline
\end{tabular}


Table 11.

Research topics ranked from most important to least important to WOMEN according to means

\begin{tabular}{|c|c|c|c|c|}
\hline Category & Topic & Mean & SD & $\mathbf{N}$ \\
\hline Postpartum Issues & $\begin{array}{l}\text { Explore women's immediate and longer-term (6 } \\
\text { months) perception of their postpartum } \\
\text { experience and physical recovery (15). } \\
\text { Subsidiary questions: } \\
\text { - Explore women's perceptions of the care } \\
\text { and advice received from midwives in } \\
\text { preparation for early parenting. } \\
\text { Explore women's perceptions of } \\
\text { postpartum community support. }\end{array}$ & 6.52 & 0.82 & 144 \\
\hline Postpartum Issue & $\begin{array}{l}\text { Assess the evidence based knowledge of both } \\
\text { women and midwives during the early postnatal } \\
\text { phase (for example, early discharge, PND and } \\
\text { the impact of labour and birth outcomes on the } \\
\text { early parenting period) (16). }\end{array}$ & 6.45 & 0.89 & 143 \\
\hline Professional Issues & $\begin{array}{l}\text { Investigate women's current expectations and } \\
\text { experiences of childbirth (3). }\end{array}$ & 6.44 & 0.89 & 151 \\
\hline Intrapartum Issues & $\begin{array}{l}\text { Investigate suturing versus none } \\
\text { suturing of perineal lacerations (14). }\end{array}$ & 6.42 & 0.93 & 148 \\
\hline Postpartum Issues & $\begin{array}{l}\text { Explore current issues related to breastfeeding } \\
\text { from the perspective of midwives, women and } \\
\text { other health care professionals (17). }\end{array}$ & 6.40 & 1.02 & 144 \\
\hline Intrapartum Issues & $\begin{array}{l}\text { Determine midwifery best practice to optimise } \\
\text { bladder function during labour and birth (13). }\end{array}$ & 6.29 & 1.16 & 149 \\
\hline Antenatal Issues & $\begin{array}{l}\text { Undertake a needs analysis of women during the } \\
\text { antenatal phase of pregnancy (6). } \\
\text { Subsidiary question: } \\
\text { - What factors influence the uptake and } \\
\text { outcome of antenatal education for women. }\end{array}$ & 6.26 & 1.01 & 150 \\
\hline Intrapartum Issues & $\begin{array}{l}\text { Explore midwives' current expectations and } \\
\text { experiences of promoting active birth strategies } \\
\text { with women in labour (8). }\end{array}$ & 6.21 & 1.02 & 151 \\
\hline Antenatal Issues & $\begin{array}{l}\text { Identify strategies to increase antenatal } \\
\text { midwifery led services (7). }\end{array}$ & 6.21 & 1.19 & 151 \\
\hline Intrapartum Issues & $\begin{array}{l}\text { Evaluate the discrepancy between evidence } \\
\text { based practice guidelines and their implication } \\
\text { in practice in relation to: Routine ARM and } 2^{\text {nd }} \\
\text { stage management (11). }\end{array}$ & 6.21 & 1.07 & 149 \\
\hline Professional Issues & $\begin{array}{l}\text { Explore women's perceptions of midwifery led } \\
\text { care (2). }\end{array}$ & 6.17 & 1.22 & 151 \\
\hline
\end{tabular}




\begin{tabular}{|c|c|c|c|c|}
\hline Intrapartum Issues & $\begin{array}{l}\text { Evaluate the discrepancy between evidence } \\
\text { based practice guidelines and their implication } \\
\text { in practice in relation to: pre-labour SROM at } \\
\text { term. (10) }\end{array}$ & 6.13 & 1.15 & 149 \\
\hline Professional Issues & $\begin{array}{l}\text { Explore the role of the midwife from the } \\
\text { perspective of midwives, women and other } \\
\text { health care professionals (1). }\end{array}$ & 6.08 & 1.21 & 151 \\
\hline Intrapartum Issues & $\begin{array}{l}\text { Evaluate the discrepancy between evidence } \\
\text { based practice guidelines and their implication } \\
\text { in practice in relation to: Electronic Fetal } \\
\text { Monitoring (9). }\end{array}$ & 6.03 & 1.21 & 149 \\
\hline Intrapartum Issues & $\begin{array}{l}\text { Explore the impact of the increasing use of } \\
\text { epidural analgesia on midwives' clinical } \\
\text { practice (12). }\end{array}$ & 5.95 & 1.26 & 149 \\
\hline Professional Issues & $\begin{array}{l}\text { Examine the professional issues that impact } \\
\text { upon midwives' clinical practice (for example, } \\
\text { midwifery and medical collaboration, potential } \\
\text { litigation and horizontal violence in the } \\
\text { workplace) (4). }\end{array}$ & 5.51 & 1.54 & 152 \\
\hline Professional Issues & $\begin{array}{l}\text { Develop a preceptorship model that promotes } \\
\text { communication between preceptors (clinicians) } \\
\text { and academic staff, and that also meets the } \\
\text { needs and requirements of both the university } \\
\text { and clinical facility (5). }\end{array}$ & 4.97 & 1.82 & 151 \\
\hline
\end{tabular}


Table 12.

Research topics ranked from most important to least important to WOMEN's FAMILIES according to means

\begin{tabular}{|c|c|c|c|c|}
\hline Category & Topic & Mean & SD & $\mathbf{N}$ \\
\hline Postpartum Issue & $\begin{array}{l}\text { Assess the evidence based knowledge of both } \\
\text { women and midwives during the early postnatal } \\
\text { phase (for example, early discharge, PND and } \\
\text { the impact of labour and birth outcomes on the } \\
\text { early parenting period) (16). }\end{array}$ & 6.27 & 1.05 & 143 \\
\hline Postpartum Issues & $\begin{array}{l}\text { Explore women’s immediate and longer-term (6 } \\
\text { months) perception of their postpartum } \\
\text { experience and physical recovery (15). } \\
\text { Subsidiary questions: } \\
\text { - Explore women's perceptions of the care } \\
\text { and advice received from midwives in } \\
\text { preparation for early parenting. } \\
\text { Explore women's perceptions of } \\
\text { postpartum community support. }\end{array}$ & 6.19 & 1.19 & 144 \\
\hline Postpartum Issues & $\begin{array}{l}\text { Explore current issues related to breastfeeding } \\
\text { from the perspective of midwives, women and } \\
\text { other health care professionals (17). }\end{array}$ & 5.92 & 1.33 & 144 \\
\hline Professional Issues & $\begin{array}{l}\text { Investigate women's current expectations and } \\
\text { experiences of childbirth (3). }\end{array}$ & 5.89 & 1.27 & 151 \\
\hline Antenatal Issues & $\begin{array}{l}\text { Identify strategies to increase antenatal } \\
\text { midwifery led services (7). }\end{array}$ & 5.74 & 1.40 & 151 \\
\hline Antenatal Issues & $\begin{array}{l}\text { Undertake a needs analysis of women during the } \\
\text { antenatal phase of pregnancy (6). } \\
\text { Subsidiary question: } \\
\text { - What factors influence the uptake and } \\
\text { outcome of antenatal education for women. }\end{array}$ & 5.65 & 1.32 & 150 \\
\hline Professional Issues & $\begin{array}{l}\text { Explore women's perceptions of midwifery led } \\
\text { care (2). }\end{array}$ & 5.53 & 1.48 & 151 \\
\hline Professional Issues & $\begin{array}{l}\text { Explore the role of the midwife from the } \\
\text { perspective of midwives, women and other } \\
\text { health care professionals (1). }\end{array}$ & 5.47 & 1.50 & 151 \\
\hline Intrapartum Issues & $\begin{array}{l}\text { Explore midwives' current expectations and } \\
\text { experiences of promoting active birth strategies } \\
\text { with women in labour (8). }\end{array}$ & 5.31 & 1.47 & 150 \\
\hline Intrapartum Issues & $\begin{array}{l}\text { Evaluate the discrepancy between evidence } \\
\text { based practice guidelines and their implication } \\
\text { in practice in relation to: pre-labour PROM at } \\
\underline{\text { term. (10) }}\end{array}$ & 5.28 & 1.59 & 149 \\
\hline Intrapartum Issues & $\begin{array}{l}\text { Investigate suturing versus none } \\
\text { suturing of perineal lacerations (14). }\end{array}$ & 5.27 & 1.60 & 148 \\
\hline
\end{tabular}




\begin{tabular}{|c|c|c|c|c|}
\hline Intrapartum Issues & $\begin{array}{l}\text { Evaluate the discrepancy between evidence } \\
\text { based practice guidelines and their implication } \\
\text { in practice in relation to: Routine ARM and } 2^{\text {nd }} \\
\text { stage management (11). }\end{array}$ & 5.14 & 1.60 & 150 \\
\hline Intrapartum Issues & $\begin{array}{l}\text { Explore the impact of the increasing use of } \\
\text { epidural analgesia on midwives' clinical } \\
\text { practice (12). }\end{array}$ & 5.13 & 1.54 & 149 \\
\hline Intrapartum Issues & $\begin{array}{l}\text { Evaluate the discrepancy between evidence } \\
\text { based practice guidelines and their implication } \\
\text { in practice in relation to: Electronic Fetal } \\
\text { Monitoring (9). }\end{array}$ & 5.13 & 1.62 & 149 \\
\hline Professional Issues & $\begin{array}{l}\text { Examine the professional issues that impact } \\
\text { upon midwives' clinical practice (for example, } \\
\text { midwifery and medical collaboration, potential } \\
\text { litigation and horizontal violence in the } \\
\text { workplace) (4). }\end{array}$ & 5.09 & 1.68 & 151 \\
\hline Intrapartum Issues & $\begin{array}{l}\text { Determine midwifery best practice to optimise } \\
\text { bladder function during labour and birth (13). }\end{array}$ & 5.09 & 1.77 & 149 \\
\hline Professional Issues & $\begin{array}{l}\text { Develop a preceptorship model that promotes } \\
\text { communication between preceptors (clinicians) } \\
\text { and academic staff, and that also meets the } \\
\text { needs and requirements of both the university } \\
\text { and clinical facility (5). }\end{array}$ & 4.48 & 1.89 & 151 \\
\hline
\end{tabular}


Table 13.

Research topics ranked from most important to least important to MIDWIVES according to means

\begin{tabular}{|c|c|c|c|c|}
\hline Category & Topic & Mean & SD & $\mathbf{N}$ \\
\hline Professional Issues & $\begin{array}{l}\text { Examine the professional issues that impact } \\
\text { upon midwives' clinical practice (for example, } \\
\text { midwifery and medical collaboration, potential } \\
\text { litigation and horizontal violence in the } \\
\text { workplace) (4). }\end{array}$ & 6.74 & 0.59 & 152 \\
\hline Antenatal Issues & $\begin{array}{l}\text { Identify strategies to increase antenatal } \\
\text { midwifery led services (7). }\end{array}$ & 6.65 & 0.69 & 151 \\
\hline Professional Issues & $\begin{array}{l}\text { Explore women's perceptions of midwifery led } \\
\text { care (2). }\end{array}$ & 6.52 & .082 & 151 \\
\hline Professional Issues & $\begin{array}{l}\text { Investigate women's current expectations and } \\
\text { experiences of childbirth (3). }\end{array}$ & 6.50 & 0.84 & 151 \\
\hline Intrapartum Issues & $\begin{array}{l}\text { Evaluate the discrepancy between evidence } \\
\text { based practice guidelines and their implication } \\
\text { in practice in relation to: pre-labour SROM at } \\
\underline{\text { term. (10) }}\end{array}$ & 6.48 & 0.83 & 149 \\
\hline Intrapartum Issues & $\begin{array}{l}\text { Explore the impact of the increasing use of } \\
\text { epidural analgesia on midwives' clinical } \\
\text { practice (12). }\end{array}$ & 6.46 & 0.85 & 149 \\
\hline Intrapartum Issues & $\begin{array}{l}\text { Evaluate the discrepancy between evidence } \\
\text { based practice guidelines and their implication } \\
\text { in practice in relation to: Routine ARM and } 2^{\text {nd }} \\
\text { stage management (11). }\end{array}$ & 6.44 & 0.87 & 149 \\
\hline Intrapartum Issues & $\begin{array}{l}\text { Evaluate the discrepancy between evidence } \\
\text { based practice guidelines and their implication } \\
\text { in practice in relation to: Electronic Fetal } \\
\text { Monitoring (9). }\end{array}$ & 6.43 & 0.84 & 149 \\
\hline Intrapartum Issues & $\begin{array}{l}\text { Explore midwives' current expectations and } \\
\text { experiences of promoting active birth strategies } \\
\text { with women in labour (8). }\end{array}$ & 6.42 & 0.81 & 151 \\
\hline Postpartum Issue & $\begin{array}{l}\text { Assess the evidence based knowledge of both } \\
\text { women and midwives during the early postnatal } \\
\text { phase (for example, early discharge, PND and } \\
\text { the impact of labour and birth outcomes on the } \\
\text { early parenting period) (16). }\end{array}$ & 6.42 & 0.89 & 143 \\
\hline Professional Issues & $\begin{array}{l}\text { Explore the role of the midwife from the } \\
\text { perspective of midwives, women and other } \\
\text { health care professionals (1). }\end{array}$ & 6.39 & 1.08 & 152 \\
\hline Postpartum Issues & $\begin{array}{l}\text { 15. Explore women's immediate and longer- } \\
\text { term ( } 6 \text { months) perception of their postpartum } \\
\text { experience and physical recovery. }\end{array}$ & 6.36 & 0.94 & 144 \\
\hline
\end{tabular}




\begin{tabular}{|c|c|c|c|c|}
\hline & $\begin{array}{l}\text { Subsidiary questions: } \\
\text { - } \quad \text { Explore women's perceptions of the care } \\
\text { and advice received from midwives in } \\
\text { preparation for early parenting. } \\
\text { - } \quad \begin{array}{l}\text { Explore women's perceptions of } \\
\text { postpartum community support. }\end{array}\end{array}$ & & & \\
\hline Intrapartum Issues & $\begin{array}{l}\text { Determine midwifery best practice to optimise } \\
\text { bladder function during labour and birth (13). }\end{array}$ & 6.34 & 1.01 & 149 \\
\hline Postpatum Issues & $\begin{array}{l}\text { Explore current issues related to breastfeeding } \\
\text { from the perspective of midwives, women and } \\
\text { other health care professionals (17). }\end{array}$ & 6.33 & 1.02 & 144 \\
\hline Antenatal Issues & $\begin{array}{l}\text { Undertake a needs analysis of women during the } \\
\text { antenatal phase of pregnancy (6). } \\
\text { Subsidiary question: } \\
\text { - What factors influence the uptake and } \\
\text { outcome of antenatal education for women. }\end{array}$ & 6.29 & 0.92 & 150 \\
\hline Intrapartum Issues & $\begin{array}{l}\text { Investigate suturing versus none } \\
\text { suturing of perineal lacerations (14). }\end{array}$ & 6.29 & 1.03 & 148 \\
\hline Professional Issues & $\begin{array}{l}\text { Develop a preceptorship model that promotes } \\
\text { communication between preceptors (clinicians) } \\
\text { and academic staff, and that also meets the } \\
\text { needs and requirements of both the university } \\
\text { and clinical facility. }\end{array}$ & 6.27 & 0.97 & 151 \\
\hline
\end{tabular}


Table 14: Three research topics ranked as least important according to means

\begin{tabular}{|c|c|c|c|c|}
\hline Category & Topic & Mean & SD & $\mathbf{N}$ \\
\hline \multicolumn{5}{|l|}{ Overall Ranking } \\
\hline Intrapartum Issues & $\begin{array}{l}\text { Explore the impact of the increasing use of } \\
\text { epidural analgesia on midwives' clinical } \\
\text { practice (12). }\end{array}$ & 17.5369 & 2.9899 & 149 \\
\hline Professional Issues & $\begin{array}{l}\text { Examine the professional issues that impact } \\
\text { upon midwives' clinical practice (for } \\
\text { example, midwifery and medical } \\
\text { collaboration, potential litigation and } \\
\text { horizontal violence in the workplace) (4). }\end{array}$ & 17.3092 & 3.3221 & 152 \\
\hline Professional Issues & $\begin{array}{l}\text { Develop a preceptorship model that } \\
\text { promotes communication between } \\
\text { preceptors (clinicians) and academic staff, } \\
\text { and that also meets the needs and } \\
\text { requirements of both the university and } \\
\text { clinical facility (5). }\end{array}$ & 15.7219 & 4.1298 & 151 \\
\hline \multicolumn{5}{|l|}{ Women's Care } \\
\hline Intrapartum Issues & $\begin{array}{l}\text { Explore the impact of the increasing use of } \\
\text { epidural analgesia on midwives' clinical } \\
\text { practice (12). }\end{array}$ & 5.95 & 1.26 & 149 \\
\hline Professional Issues & $\begin{array}{l}\text { Examine the professional issues that impact } \\
\text { upon midwives' clinical practice (for } \\
\text { example, midwifery and medical } \\
\text { collaboration, potential litigation and } \\
\text { horizontal violence in the workplace) (4). }\end{array}$ & 5.51 & 1.54 & 152 \\
\hline Professional Issues & $\begin{array}{l}\text { Develop a preceptorship model that } \\
\text { promotes communication between } \\
\text { preceptors (clinicians) and academic staff, } \\
\text { and that also meets the needs and } \\
\text { requirements of both the university and } \\
\text { clinical facility (5). }\end{array}$ & 4.97 & 1.82 & 151 \\
\hline \multicolumn{5}{|l|}{ Family Care } \\
\hline Professional Issues & $\begin{array}{l}\text { Examine the professional issues that impact } \\
\text { upon midwives' clinical practice (for } \\
\text { example, midwifery and medical } \\
\text { collaboration, potential litigation and } \\
\text { horizontal violence in the workplace) (4). }\end{array}$ & 5.09 & 1.68 & 151 \\
\hline Intrapartum Issues & $\begin{array}{l}\text { Determine midwifery best practice to } \\
\text { optimise bladder function during labour and } \\
\text { birth (13). }\end{array}$ & 5.09 & 1.77 & 149 \\
\hline Professional Issues & $\begin{array}{l}\text { Develop a preceptorship model that } \\
\text { promotes communication between } \\
\text { preceptors (clinicians) and academic staff, } \\
\text { and that also meets the needs and } \\
\text { requirements of both the university and } \\
\text { clinical facility (5). }\end{array}$ & 4.48 & 1.89 & 151 \\
\hline \multicolumn{5}{|l|}{ Midwives } \\
\hline Antenatal Issues & $\begin{array}{l}\text { Undertake a needs analysis of women } \\
\text { during the antenatal phase of pregnancy (6). } \\
\text { Subsidiary question: } \\
\text { - What factors influence the uptake and } \\
\text { outcome of antenatal education for } \\
\text { women. }\end{array}$ & 6.29 & 0.92 & 150 \\
\hline
\end{tabular}




\begin{tabular}{|l|l|c|c|c|}
\hline Intrapartum Issues & $\begin{array}{l}\text { Investigate suturing versus none suturing of } \\
\text { perineal lacerations (14). }\end{array}$ & 6.29 & 1.03 & 148 \\
\hline Professional Issues & $\begin{array}{l}\text { Develop a preceptorship model that } \\
\text { promotes communication between } \\
\text { preceptors (clinicians) and academic staff, } \\
\text { and that also meets the needs and } \\
\text { requirements of both the university and } \\
\text { clinical facility. }\end{array}$ & 6.27 & 0.97 & 151 \\
\hline
\end{tabular}




\section{APPENDIX 1: Round two research statements}

\section{Professional Issues}

1. Explore the role of the midwife from the perspective of midwives, women and other health care professionals.

2. Explore women's perceptions of midwifery led care.

3. Investigate women's current expectations and experiences of childbirth.

4. Examine the professional issues that impact upon midwives' clinical practice (for example, midwifery and medical collaboration, potential litigation and horizontal violence in the workplace).

5. Develop a preceptorship model that promotes communication between preceptors (clinicians) and academic staff, and that also meets the needs and requirements of both the university and clinical facility.

\section{Antenatal Issues}

6. Undertake a needs analysis of women during the antenatal phase of pregnancy. Subsidiary question:

- What factors influence the uptake and outcome of antenatal education for women. 7. Identify strategies to increase antenatal midwifery led services.

\section{Intrapartum Issues}

8. Explore midwives' current expectations and experiences of promoting active birth strategies with women in labour.

9. Evaluate the discrepancy between evidence based practice guidelines and their implication in practice in relation to: Electronic Fetal Monitoring. 10. Evaluate the discrepancy between evidence based practice guidelines and their implication in practice in relation to: pre-labour SROM at term.

11. Evaluate the discrepancy between evidence based practice guidelines and their implication in practice in relation to: Routine ARM and $2^{\text {nd }}$ stage management. 12. Explore the impact of the increasing use of epidural analgesia on midwives' clinical practice.

13. Determine midwifery best practice to optimise bladder function during labour and birth. 14. Investigate suturing versus none suturing of perineal lacerations.

\section{Postpartum Issues}

15. Explore women's immediate and longer-term (6 months) perception of their postpartum experience and physical recovery.

Subsidiary questions:

- Explore women's perceptions of the care and advice received from midwives in preparation for early parenting.

- Explore women's perceptions of postpartum community support.

16. Assess the evidence based knowledge of both women and midwives during the early postnatal phase (for example, early discharge, PND and the impact of labour and birth outcomes on the early parenting period).

17. Explore current issues related to breastfeeding from the perspective of midwives, women and other health care professionals. 